\title{
A unique bacteriohopanetetrol stereoisomer of marine anammox
}

\author{
Rachel Schwartz-Narbonne ${ }^{\mathrm{a}, 1, *}$, Philippe Schaeffer ${ }^{\mathrm{b}}$, Ellen C. Hopmans ${ }^{\mathrm{c}}$, Margot Schenesse ${ }^{\mathrm{b}}$, \\ E. Alex Charlton ${ }^{\mathrm{a}}$, D. Martin Jones ${ }^{\mathrm{a}}$, Jaap S. Sinninghe Damsté ${ }^{\mathrm{c}, \mathrm{d}}$, Muhammad Farhan Ul Haque ${ }^{\mathrm{e}, \mathrm{f}}$, \\ Mike S.M. Jetten ${ }^{\mathrm{g}}$, Sabine K. Lengger ${ }^{\mathrm{h}}$, J. Colin Murrell ${ }^{\mathrm{e}}$, Philippe Normand ${ }^{\mathrm{i}}$, Guylaine H.L. Nuijten ${ }^{\mathrm{g}}$, \\ Helen M. Talbot ${ }^{\mathrm{a}, \mathrm{j}}$, Darci Rush ${ }^{\mathrm{a}, \mathrm{c}}$

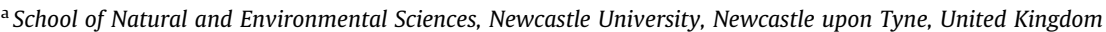 \\ ${ }^{\mathrm{b}}$ Université de Strasbourg-CNRS, UMR 7177, Strasbourg, France

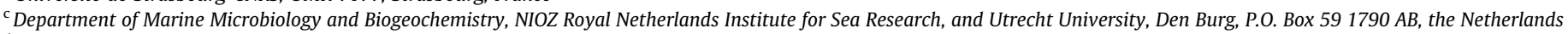 \\ ${ }^{\mathrm{d}}$ Department of Earth Sciences, Faculty of Geosciences, Utrecht University, Utrecht, the Netherlands \\ e School of Environmental Sciences, University of East Anglia, Norwich Research Park, Norwich NR4 7TJ, United Kingdom \\ ${ }^{\mathrm{f}}$ School of Biological Sciences, University of the Punjab, Lahore, Pakistan \\ ${ }^{\mathrm{g}}$ Department of Microbiology, Radboud University, Nijmegen, the Netherlands \\ ${ }^{\mathrm{h}}$ Biogeochemistry Research Centre, School of Geography, Earth and Environmental Sciences, University of Plymouth, Plymouth, United Kingdom

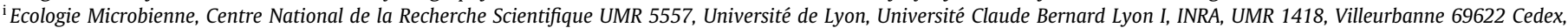 \\ France \\ j BioArCh, Department of Archaeology, University of York, York YO10 5DD, United Kingdom
}

\section{A R T I C L E I N F O}

\section{Article history:}

Received 26 October 2019

Received in revised form 21 February 2020

Accepted 21 February 2020

Available online 25 February 2020

\section{Keywords:}

Bacteriohopanepolyols

Bacteriohopanetetrols

Stereoisomers

Anammox

Biomarkers

\begin{abstract}
A B S T R A C T
Anaerobic ammonium oxidation (anammox) is a major process of bioavailable nitrogen removal from marine systems. Previously, a bacteriohopanetetrol (BHT) isomer, with unknown stereochemistry, eluting later than BHT when examined by high performance liquid chromatography (HPLC), was detected in ' $\mathrm{Ca}$. Scalindua profunda' and proposed as a biomarker for anammox in marine paleo-environments. However, the utility of this BHT isomer as an anammox biomarker is hindered by the fact that four other, non-anammox, bacteria are also known to produce a late-eluting BHT stereoisomer. The stereochemistry in Acetobacter pasteurianus, Komagataeibacter xylinus and Frankia sp. was known to be $17 \beta, 21 \beta(\mathrm{H}), 22 R$, $32 R, 33 R, 34 R$ (BHT-34R). The stereochemistry of the late-eluting BHT in Methylocella palustris was unknown. To determine if marine anammox bacteria produce a unique BHT isomer, we studied the BHT distributions and stereochemistry of known BHT isomer producers and of previously unscreened marine ('Ca. Scalindua brodeae') and freshwater ('Ca. Brocadia spp.') anammox bacteria, using HPLC and gas chromatographiy (GC) analysis of acetylated BHTs and ultra high performance liquid chromatography (UHPLC)-high resolution mass spectrometry (HRMS) analysis of non-acetylated BHTs. The $34 R$ stereochemistry was confirmed for the BHT isomers in Ca. Brocadia sp. and Methylocella palustris. However, 'Ca. Scalindua spp.' synthesises a stereochemically distinct BHT isomer, with still unconfirmed stereochemistry (BHT- $x$ ). Only GC analysis of acetylated BHT and UHPLC analysis of non-acetylated BHT distinguished between late-eluting BHT isomers. Acetylated BHT- $x$ and BHT-34R co-elute when examined by HPLC. As BHT- $x$ is currently only known to be produced by 'Ca. Scalindua spp.', it may be a biomarker for marine anammox.
\end{abstract}

(c) 2020 The Author(s). Published by Elsevier Ltd. This is an open access article under the CC BY license (http://creativecommons.org/licenses/by/4.0/).

\section{Introduction}

In anoxic and low-oxygen marine systems, anaerobic ammonium oxidation (anammox) removes bioavailable nitrogen by

\footnotetext{
* Corresponding author.

E-mail addresses: r.schwartz-narbonne@shu.ac.uk (R. Schwartz-Narbonne), darci.rush@nioz.nl (D. Rush).

${ }^{1}$ Present address: Biomolecular Sciences Research Centre, Sheffield Hallam University, Sheffield S1 1WB, United Kingdom.
}

converting ammonium and nitrite into dinitrogen gas (Strous et al., 1999). This limits the availability of a major nutrient for phytoplankton and thus may have pronounced effects on biogeochemical cycling in the ocean. Marine anammox is suggested to account for ca. $30 \%$ of the loss of bioavailable nitrogen from the global oceans today (Ward, 2013). Reconstructing the presence of anammox in paleo-environments is therefore particularly important for understanding the changes in the nitrogen cycle.

Anammox is performed by bacteria belonging to the Planctomycetes. Anammox was first recognized in an anaerobic waste 
water treatment system (Strous et al., 1999) and subsequently in the environment (Kuypers et al., 2003). Amongst the five currently known genera of anammox bacteria, four are primarily found in non-marine/freshwater environments: 'Candidatus Brocadia', 'Ca. Jettenia', 'Ca. Kuenenia' and 'Ca. Anammoxoglobus' (Kartal et al., 2007; Kuypers et al., 2003; Quan et al., 2008; Schmid et al., 2000; Strous et al., 1999). 'Ca. Scalindua' genus is typically reported only in marine systems (Schmid et al., 2007; Woebken et al., 2007; Villanueva et al., 2014), although it was also reported to be the dominant genus in a rice paddy (Wang and $\mathrm{Gu}, 2013$ ).

Ladderane lipids are also used as biomarkers for the detection of anammox. These highly specific lipids possess three or five concatenated cyclobutyl moieties and are synthesized exclusively by anammox bacteria (Sinninghe Damsté et al., 2002). However, the strained nature of the cyclobutyl moieties of these lipids means ladderanes are transformed relatively quickly during sediment burial (Jaeschke et al., 2008; Rush et al., 2012). The oldest detected ladderanes are from marine sediments of ca. 140,000 yr (Jaeschke et al., 2008). Therefore, the presence of anammox in much older sediments cannot be evaluated using these biomarkers (Jaeschke et al., 2008; Rush and Sinninghe Damsté, 2017; Rush et al., 2012, 2019).

Bacteriohopanepolyols (BHPs) are lipids produced by both aerobic and anaerobic bacteria (Belin et al., 2018; Rohmer et al., 1984; Talbot et al., 2007a), including anammox bacteria (Sinninghe Damsté et al., 2004). BHPs have been found to be preserved for 55 Myr (Talbot et al., 2016; van Dongen et al., 2006), making them viable biomarkers in many sedimentary records. Bacteriohopanetetrol (bacteriohopane-17 $\beta, 21 \beta(\mathrm{H}), 22 R, 32 R, 33 R, 34 S$, 35tetrol; hence referred to as BHT-34S; Fig. 1a) is ubiquitous in the environment (Bisseret and Rohmer, 1989; Talbot et al., 2003; Talbot and Farrimond, 2007) and has been shown to be produced by a diverse array of bacteria (Rohmer et al., 1984; Talbot et al., 2007a; Talbot and Farrimond, 2007 and references therein). Marine suspended particulate matter (SPM) from anoxic and low-oxygen water columns and marine sediments have also been found to contain a late-eluting BHT isomer (Berndmeyer et al., 2014, 2013; Blumenberg et al., 2010; Kharbush et al., 2013; Kusch et al., 2018; Rush et al., 2014; Sáenz et al., 2011; Wakeham et al., 2012). The fractional abundance of late-eluting 'marine BHT isomer' was proposed as a way to assess anoxia levels in marine environments, as the ratio of BHT isomer to BHT was found to correlate with anoxia in multiple marine environments (Sáenz et al., 2011). Rush et al. (2014) identified BHT-34S, as well as a late-eluting stereoisomer of BHT, using high pressure liquid chromatographyatmospheric pressure chemical ionization/mass spectrometry (HPLC-APCI/MS analysis) (Talbot et al., 2007a) in an enrichment culture of the marine anammox species ' $\mathrm{Ca}$. Scalindua profunda' (van de Vossenberg et al., 2008, 2013). Further evidence linking this 'marine BHT isomer' to ' $\mathrm{Ca}$. Scalindua spp.' was found by correlating the concentration of the BHT isomer with that of ladderanes (Rush et al., 2014, 2019), with $\delta^{15} \mathrm{~N}$ and with genomic information (Matys et al., 2017), and with low $\delta^{13} \mathrm{C}$ values in the late-eluting BHT isomer from anoxic marine datasets (Lengger et al., 2019; Hemingway et al., 2018). It was, therefore, proposed that this late-eluting BHT isomer is a more appropriate biomarker for the presence of marine anammox in the deeper sedimentary record than ladderanes (Rush et al., 2014, 2019).

Some ambiguity remains in the use of late-eluting BHT isomer as a biomarker for marine anammox. To the best of our knowledge, a late-eluting BHT isomer has been reported in four other bacterial cultures (Rush et al., 2014): the aerobic, terrestrial nitrogen-fixing bacteria Frankia spp. (Rosa-Putra et al., 2001), the acetic acid bacteria Acetobacter pasteurianus and Komagataeibacter xylinus (formerly Gluconacetobacter xylinus and A. aceti ssp. xylinum) (Peiseler and Rohmer, 1992), and the Type II methanotrophic bacterium Methylocella palustris (van Winden et al., 2012). Unlike 'Ca. Scalindua profunda', these four bacteria are all non-marine, aerobic bacteria. Thus, the presence of a late-eluting BHT isomer in anoxic, marine environments, with no terrigenous contribution, can be regarded as indicative of the presence of ' $\mathrm{Ca}$. Scalindua' or some other, as yet unidentified, marine anammox genera (Rush et al.,

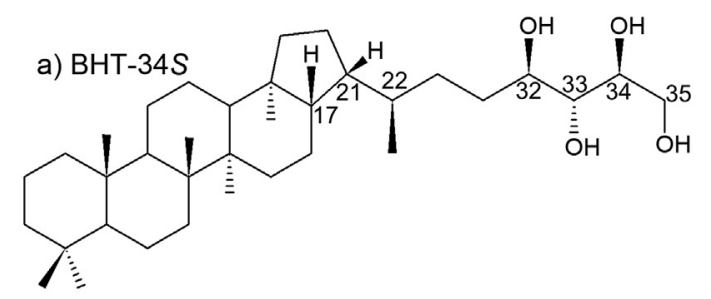

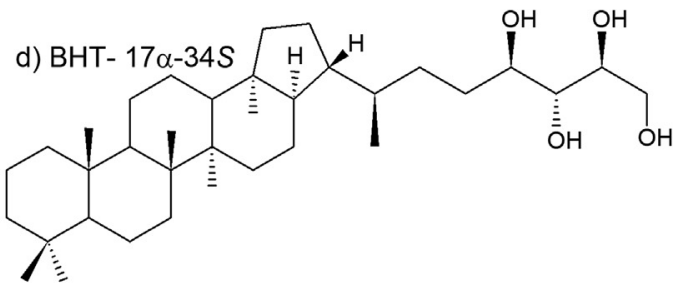

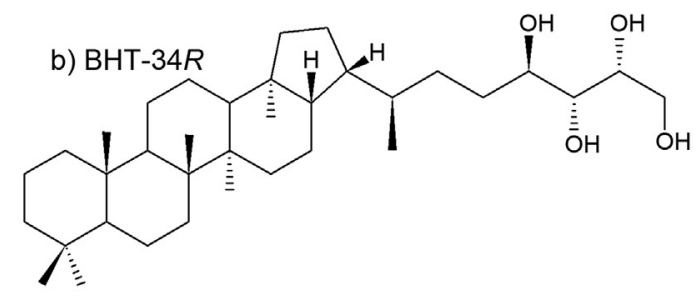

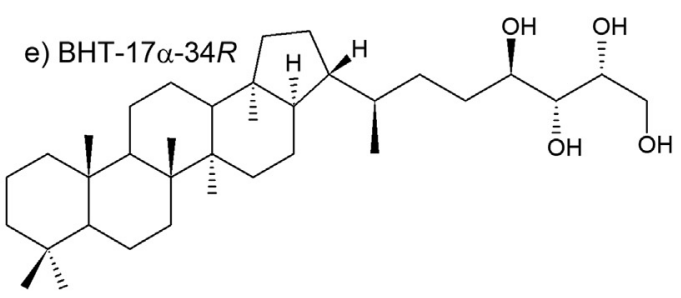

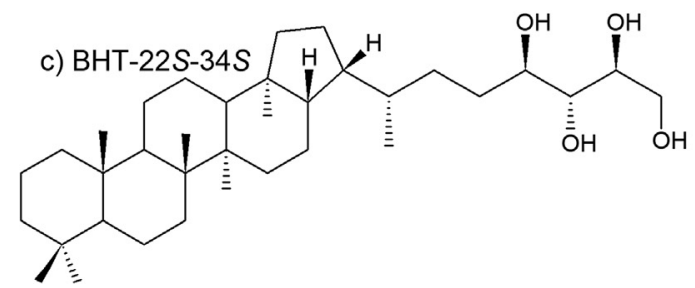

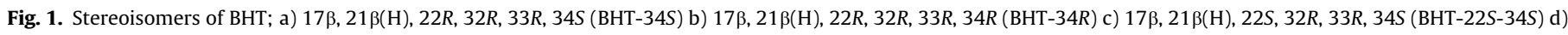
$17 \alpha, 21 \beta(\mathrm{H}), 22 R, 32 R, 33 R, 34 S$ (BHT-17 $\alpha-34 S$ ) and e) BHT-17 $\alpha, 21 \beta(\mathrm{H}), 22 R, 32 R, 33 R, 34 R$ (BHT-17 $\alpha-34 R$ ). Carbon numbering shown on a) BHT-34S. 
2014). Low concentrations of a later-eluting BHT isomer also have been found in non-marine environments, though the source has not been determined (Talbot et al., 2003), as well as in oxic marine environments, though these were associated with anoxic environments (Matys et al., 2017; Kusch et al., 2018). The stereochemistry of the late-eluting BHT isomer in A. pasteurianus, K. xylinus and Frankia spp. has been shown to be $17 \beta, 21 \beta(\mathrm{H}), 22 R, 32 R, 33 R$, $34 R$ (BHT-34R; Fig. 1b) (Peiseler and Rohmer, 1992; Rosa-Putra et al., 2001). A number of early eluting BHT isomers also have been found, both in non-anammox bacterial cultures (Peiseler and Rohmer, 1992; Rosa-Putra et al., 2001) and in marine sediments (Kusch et al., 2018). Studies of bacterial cultures with BHT isomers of known stereochemistry have found that, when measured as their acetylated derivatives by gas chromatography (GC) and HPLC, isomers with distinct ring stereochemistry elute before BHT-34S (Fig. 1 c-e) (Talbot et al., 2007b, 2008).

Here, we provide further insight into these biomarkers. We examined the stereochemistry and distributions of the BHT isomers of unknown structure produced by two marine anammox organisms of the genus ' $\mathrm{Ca}$. Scalindua'-' $\mathrm{Ca}$. Scalindua profunda' and 'Ca. Scalindua brodeae'- as well as by Methylocella palustris. We also investigated an unscreened anammox enrichment culture of 'Ca. Brocadia sp.' for the presence of late-eluting BHT isomers and re-evaluated a culture of ' $\mathrm{Ca}$. Kuenenia stuttgartiensis' to determine if trace quantities of late-eluting BHT isomer were present in this non-marine anammox bacterium.

\section{Materials and methods}

\subsection{Bacterial cultures and enrichments}

\subsubsection{Anammox enrichments}

The enrichment culture of ' $\mathrm{Ca}$. Scalindua brodeae' was maintained in an anoxic sequencing batch bioreactor at Radboud University, Nijmegen, The Netherlands. 'Ca. S. brodeae' was grown with a sea salt medium containing $33 \mathrm{~g} \mathrm{~L}^{-1}$ sea salt (Red Sea Salt, Dabrowski Aquaria, Nijmegen, NL), $\mathrm{FeSO}_{4}, \mathrm{KH}_{2} \mathrm{PO}_{4}$ and substrates of ammonium and nitrite at room temperature $\left(20^{\circ} \mathrm{C}\right)$. To maintain anoxic conditions, the bioreactor was continuously flushed with $\mathrm{Ar} / \mathrm{CO}_{2}(95 / 5 \% \mathrm{v} / \mathrm{v})$ at a rate of $10 \mathrm{~mL} / \mathrm{min}$. The $\mathrm{pH}$ was controlled at 7.3 with $100 \mathrm{~g} \mathrm{~L}^{-1} \mathrm{KHCO}_{3}$ (Speth et al., 2015; Russ et al., 2014; van de Vossenberg et al., 2008).

The enrichment cultures of fresh water ' $\mathrm{Ca}$. Brocadia sp.' were maintained in anoxic membrane bioreactors at Radboud University, Nijmegen, The Netherlands at $33^{\circ} \mathrm{C}$. Mineral medium containing trace element solution, $\mathrm{FeSO}_{4}, \mathrm{KHCO}_{3}, \mathrm{CaCl}_{2}, \mathrm{MgSO}_{4}$ and substrates $\mathrm{NH}_{4}^{+}$and $\mathrm{NO}_{2}$ was supplied continuously (Kartal et al., 2011, van de Graaf et al., 1995). Anoxic conditions and pH were maintained as described above.

All anammox cultures were harvested from the reactor and centrifuged $\left(4000 \mathrm{~g}, 20 \mathrm{~min}, 4^{\circ} \mathrm{C}\right)$ to obtain cell pellets, which were subsequently freeze-dried prior to analysis.

\subsubsection{Other bacterial cultures}

Frankia sp. strain Ea1-12 (DSM107422) (Fernandez et al., 1989) was cultivated in liquid medium containing ammonium, using a modification of a previously published method (Alloisio et al., 2010). The medium was modified to contain no vitamins and iron citrate was replaced by iron [III] chloride, at a final concentration of $20 \mu \mathrm{M}$ (medium FBM). The cells were inoculated at an Optical Density (OD)600 of 0.1 and grown for 14 days in $200 \mathrm{~mL}$ until they reached an OD600 of 0.6. Cells were then harvested by centrifugation at $5000 \mathrm{~g}$ for $10 \mathrm{~min}$.

M. palustris strain $\mathrm{K}$ was cultivated in $20 \mathrm{~mL}$ of modified dilute nitrate mineral salts medium (Farhan Ul Haque et al., 2019) in
$120 \mathrm{~mL}$ serum vials to which $20 \%(\mathrm{v} / \mathrm{v})$ methane in air was added. Vials were incubated at $25^{\circ} \mathrm{C}$ with shaking (as described by Crombie and Murrell, 2014). Cultures were harvested at an OD $(540 \mathrm{~nm})$ of 0.12 , pelleted by centrifugation at $10000 \mathrm{~g}$, and then stored at $4{ }^{\circ} \mathrm{C}$ until analysis.

K. xylinus strain R-2277 (gift from Prof. M. Rohmer) was obtained as frozen cells in culture medium from an industrial culture (Hoffmann-La Roche, Basel), grown under confidential conditions. The cells were used to isolate a BHT isomer standard. This was an aliquot of the same sample of $K$. xylinus originally studied by Peiseler and Rohmer (1992).

\subsection{BHP extraction methods}

Bacterial biomass was extracted following a modified Bligh \& Dyer extraction (BDE) method (Cooke et al., 2008). Freeze-dried biomass (>100 mg) in a $50 \mathrm{~mL}$ Teflon centrifuge tube was extracted using a monophasic mixture of water/methanol/chloroform $(4 \mathrm{~mL} / 10 \mathrm{~mL} / 5 \mathrm{~mL})$, sonicated for $15 \mathrm{~min}$ at $40^{\circ} \mathrm{C}$, followed by centrifugation at $4000 \mathrm{rpm}$ for $5 \mathrm{~min}$. The supernatant was transferred to a second centrifuge tube. The cellular residue pellet was reextracted twice using the same methods, to third and fourth centrifuge tubes. Chloroform $(5 \mathrm{~mL})$ and water $(5 \mathrm{~mL})$ were added to centrifuge tubes 2-4 to obtain a biphasic mixture. These were centrifuged at $4000 \mathrm{rpm}$ for $5 \mathrm{~min}$ and the chloroform layers were removed, combined and taken to near dryness using a rotary evaporator. The BDE was transferred to vials using a solution of chloroform/methanol $(2: 1 ; \mathrm{v} / \mathrm{v})$ and evaporated to dryness at $40{ }^{\circ} \mathrm{C}$ under a stream of $\mathrm{N}_{2}$.

\subsection{Preparation of acetylated BHT-34R and BHT-34S standards}

A batch (not weighed) of a wet biomass of $K$. xylinus was used to prepare and isolate BHT-34R, to serve as an authentic standard, since the stereochemistry has previously been verified by NMR spectroscopy (Peiseler and Rohmer, 1992). The total lipid extract (TLE) was recovered under magnetic stirring at $40^{\circ} \mathrm{C}$ using $1 \mathrm{~L}$ acetone for $40 \mathrm{~min}$ and subsequently a mixture of dichloromethane/ methanol $(1: 1 \mathrm{v} / \mathrm{v} ; 1000 \mathrm{~mL}, \mathrm{x} \mathrm{3})$ for $40 \mathrm{~min}$. At each step, the supernatant was recovered by filtration over celite after decanting, with the cells returned back for the next extraction step. At the last filtration step, the celite was rinsed with both dichloromethane and methanol (cf. Schaeffer et al., 2010). The extracts were combined, the solvent was removed under vacuum and BHPs were acetylated as described in Section 2.5.1.

K. xylinus strain R-2277 produces BHT-34R in minute amounts, but biosynthesizes $\Delta^{6}$-BHT-34R as a predominant BHT (Peiseler and Rohmer, 1992). Catalytic hydrogenation of a chromatographic fraction enriched in $\Delta^{6}$-BHT-34R separated from the acetylated TLE from K. xylinus (Supplementary Fig. S1a) was used to increase the yield of BHT-34R. It is worth noting that hydrogenation of the sterically-hindered $\Delta^{6}$ position could only be achieved under harsh conditions ( $\mathrm{Pd} / \mathrm{C}$ under pressure at 50 bars and $60^{\circ} \mathrm{C}$ over 4 days), leading to a mixture of predominantly hydrogenated BHTs and minor amounts of unreacted $\Delta^{6}$-BHTs (Supplementary Fig. S1b). Separation of the hydrogenated BHTs using silica gel column chromatography and thin layer chromatography (TLC) followed by $\mathrm{C}_{18}$ reverse phase HPLC yielded an isolate of BHT-34R with a purity of ca. 96\% (Supplementary Fig. S1e).

An acetylated BHT-34S standard isolated from the bacterium Zymomonas mobilis in a previous study (cf. Schaeffer et al., 2010) was used as a standard for co-injection in GC-FID and GC-MS co-elution experiments. The stereochemical structure of the acetylated BHT-34R and BHT-34S side chains was confirmed using 1and 2-dimensional ${ }^{1} \mathrm{H}$ and ${ }^{13} \mathrm{C}$ NMR spectroscopy experiments. 
Detailed separation methods and NMR data are reported in the supplementary material (Section 1 and Section 2).

\subsection{Isolation of non-derivatised BHT-34S and late-eluting BHT isomers from anammox biomass}

A multidimensional 3-step isolation procedure was employed to isolate BHT-34S and the late-eluting BHT stereoisomers with previously unconfirmed stereochemistries which were isolated separately from both ' $\mathrm{Ca}$. Brocadia sp.' and ' $\mathrm{Ca}$. Scalindua brodeae' (detailed procedures are shown in Supplementary Material Section 3). Although pure compounds were not obtained, fractions enriched in either BHT-34S or BHT isomers (enriched BHT fraction) with minimal interfering lipids were recovered (Supplementary Material Section 3).

\subsection{Analysis of acetylated BHTs}

\subsubsection{Acetylation}

'Ca. Scalindua profunda' and ' $\mathrm{Ca}$. Kuenenia stuttgartiensis' BDE had been previously extracted, acetylated, and measured by HPLC-APCI-MS (Rush et al., 2014) and, following re-acetylation, were also used in this study. Aliquots of BDEs of $\mathrm{Ca}$. Scalindua profunda', Frankia sp. strain Ea1-12, Methylocella palustris, partially purified 'Ca. Brocadia sp.', and partially purified 'Ca. Scalindua brodeae and of the TLE of K. xylinus strain R-2277 were acetylated prior to GC-FID, GC-MS, and HPLC-MS analysis. Equal volumes of acetic anhydride and pyridine were added to the extracts, and they were heated at $60^{\circ} \mathrm{C}$ for $1 \mathrm{~h}$. The excess of reagents was evaporated to dryness under a stream of $\mathrm{N}_{2}$ or under vacuum.

\subsubsection{GC-FID}

Gas chromatography with flame ionisation detection (GC-FID) analyses of acetylated samples dissolved in ethyl acetate were carried out on a Agilent Technologies 7890A gas chromatograph equipped with an on-column injector, a flame ionization detector and a HP-5 fused silica capillary column $(30 \mathrm{~m} \times 0.32 \mathrm{~mm}$; $0.25 \mu \mathrm{m}$ film thickness). $\mathrm{H}_{2}$ was used as carrier gas (constant flow, $2.5 \mathrm{~mL} \mathrm{~min}^{-1}$ ), and the oven was programmed as follows: $70-$ $320^{\circ} \mathrm{C}\left(10^{\circ} \mathrm{C} \mathrm{min}^{-1}\right), 60 \mathrm{~min}$ isothermal at $320^{\circ} \mathrm{C}$. Samples were injected individually and co-injected with acetylated BHT-34R or BHT-34S standard.

\subsubsection{GC-MS}

Gas chromatography-mass spectrometry (GC-MS) analyses of acetylated BHTs were carried out using a Thermo Trace gas chromatograph (Thermo Scientific) coupled to a Thermo Scientific TSQ Quantum mass spectrometer equipped with a programmed temperature vaporizing (PTV) injector. The temperature of the source was set at $220^{\circ} \mathrm{C}$. The mass spectrometer was operated in electron impact (EI) mode at $70 \mathrm{eV}$ and scanning $\mathrm{m} / \mathrm{z} 50$ to 850 . Gas chromatographic separations were performed using a HP5MS column ( $30 \mathrm{~m} \times 0.25 \mathrm{~mm}$; $0.1 \mu \mathrm{m}$ film thickness) with $\mathrm{He}$ as carrier gas (constant flow rate of $1.2 \mathrm{~mL} \mathrm{~min}^{-1}$ ). The oven temperature was programmed as follows: $70^{\circ} \mathrm{C}(1 \mathrm{~min}), 70-320^{\circ} \mathrm{C}$ $\left(10^{\circ} \mathrm{C} \mathrm{min}^{-1}\right), 40 \mathrm{~min}$ isothermal at $320^{\circ} \mathrm{C}$.

\subsubsection{HPLC-MS}

High performance liquid chromatography- mass spectrometry (HPLC-MS) analyses of BHTs were performed using an autoinjector-equipped HP 1100 series HPLC interfaced to a Bruker Esquire $3000^{+}$ion trap mass spectrometer and Chemstation chromatography manager software. Separation was achieved on a Zorbax ODS column $(4.6 \mathrm{~mm} \times 250 \mathrm{~mm}, 5 \mu \mathrm{m})$ maintained at $30{ }^{\circ} \mathrm{C}$. The injection volume was $10 \mu \mathrm{L}$. Compounds were eluted isocratically using a mixture of methanol/isopropanol 95:5 v/v as the mobile phase, with a flow rate of $1.0 \mathrm{~mL} \mathrm{~min}^{-1}$. Detection was achieved using a positive ion atmospheric pressure chemical ionization (APCI). Conditions for APCI-MS analyses were: nebulizer pressure $43.5 \mathrm{psi}$, vaporizer temperature $420^{\circ} \mathrm{C}$, drying gas $\left(\mathrm{N}_{2}\right)$ flow $6 \mathrm{~L} \mathrm{~min}{ }^{-1}$ and temperature $350^{\circ} \mathrm{C}$, capillary voltage $-4 \mathrm{kV}$, corona $4 \mu \mathrm{A}$, scanning range $m / z 300-800$.

\subsection{UHPLC-HRMS measurement of non-derivatised BHTS}

Non-derivatised samples were analysed by ultra high performance liquid chromatography - high resolution mass spectrometry (UHPLC-HRMS) using a Q Exactive Orbitrap MS system (Thermo Scientific) following previous methods (Rush et al., 2019 modification of Wörmer et al., 2013). Briefly, a solvent gradient was run using an Acquity $\mathrm{BEH} \mathrm{C}_{18}$ column (Waters, $2.1 \times 150 \mathrm{~mm}$, $1.7 \mu \mathrm{m})$ at $30^{\circ} \mathrm{C}$. Solvent $\mathrm{A}$ was methanol/water/formic acid/14.8 $\mathrm{M} \mathrm{NH}_{3 \mathrm{aq}}(85: 15: 0.12: 0.04[\mathrm{v} / \mathrm{v} / \mathrm{v} / \mathrm{v}])$ and $\mathrm{B}$ was IPA/ methanol/formic acid/14.8 $\mathrm{M} \mathrm{NH}_{3 \mathrm{aq}}$ (50:50:0.12:0.04 [v/v/v/v]), with an initial percentage of $95 \%$ A for $3 \mathrm{~min}$, decreased to $40 \% \mathrm{~A}$ at $12 \mathrm{~min}$, then decreased to $0 \% \mathrm{~A}$ at $50 \mathrm{~min}$ and maintained until $80 \mathrm{~min}$, with a flow rate of $0.2 \mathrm{~mL} \mathrm{~min}^{-1}$. Positive ion electrospray ionisation (ESI) with a capillary temperature of $300^{\circ} \mathrm{C}$ was used. ESI sheath gas $\left(\mathrm{N}_{2}\right)$ pressure was 40 arbitrary units and the auxiliary gas $\left(\mathrm{N}_{2}\right)$ pressure was 10 arbitrary units. The spray voltage was $4.5 \mathrm{kV}$, the probe heater temperature was $50{ }^{\circ} \mathrm{C}$ and the $\mathrm{S}$ lens voltage was $70 \mathrm{~V}$. Target lipids were analysed following previously described methods and parameters (Besseling et al., 2018; Rush et al., 2019; Wörmer et al., 2013) using a mass range of $m / z$ $350-2000$ (resolution $70,000 \mathrm{ppm}$ at $\mathrm{m} / \mathrm{z} 200$ ) and then datadependent tandem $\mathrm{MS}^{2}$. Integrations were made on the summed mass chromatograms (within $3 \mathrm{ppm}$ ) of the $[\mathrm{M}+\mathrm{H}]^{+},\left[\mathrm{M}+\mathrm{NH}_{4}\right]^{+}$, and $[\mathrm{M}+\mathrm{Na}]^{+}(\mathrm{m} / \mathrm{z} 547.472,564.499$, and 569.454, respectively) of non-acytelated BHT. BDEs were injected for all samples except 'Ca. Scalindua profunda': a) Frankia spp. Ea1-12, b) Komagataeibacter xylinus, c) Methylocella palustris, d) 'Ca. Brocadia sp.', e) 'Ca. Scalindua brodae', and f) 'Ca. Kuenenia stuttgartiensis'.

\section{Results \& discussion}

\subsection{Chromatographic separation and identification of late-eluting BHT isomers}

Analyses of acetylated BDEs from M. palustris, A. pasteurianus, $K$. xylinus, Frankia spp., 'Ca. Brocadia sp.', 'Ca. S. profunda' and 'Ca. S. brodeae' revealed that all contained a BHT isomer that eluted after BHT-34S when measured using HPLC and GC, and non-acetylated BDE measured by UHPLC (Figs. 2-4; Lengger et al., 2019; Peiseler and Rohmer, 1992; Rosa-Putra et al., 2001; Rush et al., 2014, 2019; van Winden et al., 2012). Since it is likely that identifying the stereochemistry of these isomers may allow for better application of late-eluting BHT isomers as biomarkers for marine anammox, further characterisation was undertaken as detailed below.

\subsubsection{Distribution of BHT isomer in bacterial cultures reveals unique marine anammox biomarker}

The BHT distributions in these cultures were measured using a recently developed UHPLC-HRMS method for the analysis of nonderivatized BHTs (Rush et al., 2019; Fig. 2). All known nonmarine producers of BHT isomers (Frankia sp., K. xylinus, M. palustris, and ' $\mathrm{Ca}$. Brocadia sp.') were shown to produce a late-eluting BHT isomer with the same retention time. The isolated lateeluting BHT isomers synthesised by A. pasteurianus, K. xylinus and Frankia spp. were previously analysed by NMR spectroscopy and all were found to possess the BHT-34R stereochemistry (Peiseler and Rohmer, 1992; Rosa-Putra et al., 2001). In contrast, the marine 


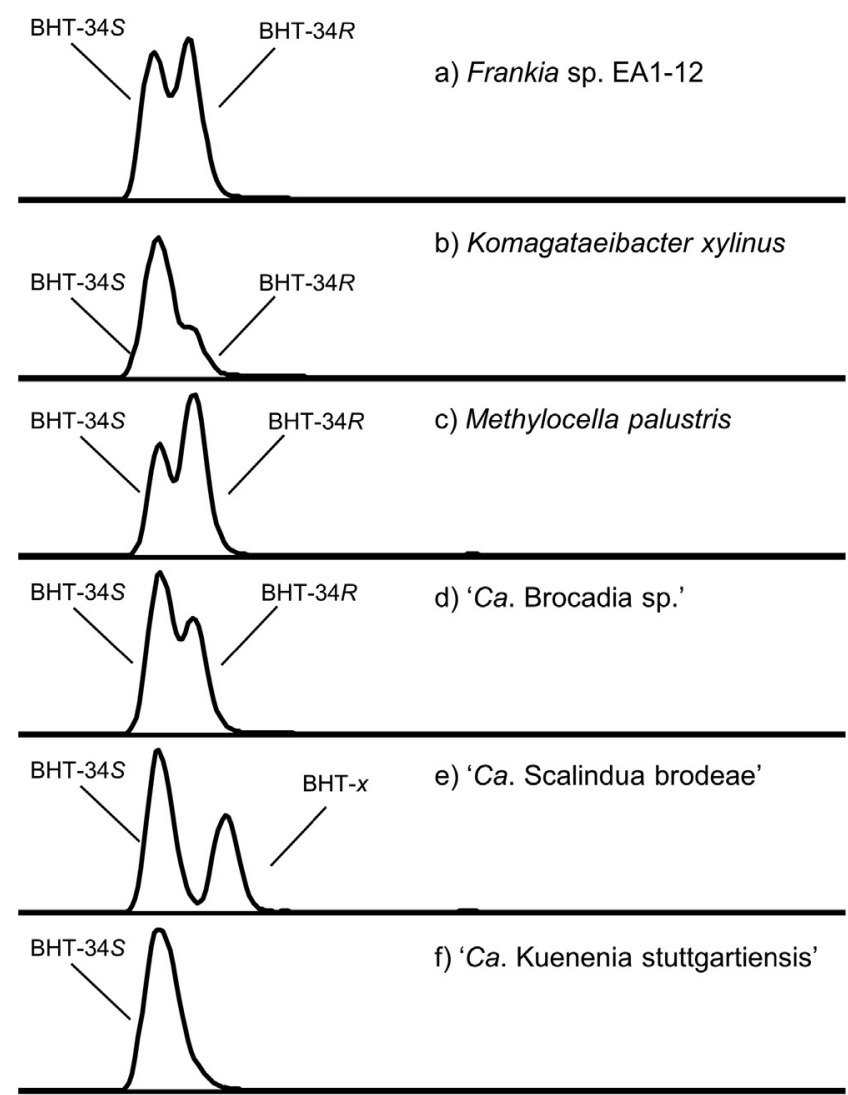

Time

Fig. 2. UHPLC-HRMS combined mass chromatograms (within $3 \mathrm{ppm}$ ) of the $[\mathrm{M}+\mathrm{H}]^{+}$, $\left[\mathrm{M}+\mathrm{NH}_{4}\right]^{+}$, and $[\mathrm{M}+\mathrm{Na}]^{+}(\mathrm{m} / \mathrm{z} 547.472,564.499$, and 569.454, respectively) of nonacetylated BHT and isomers of a) Frankia sp. Ea1-12b) Komagataeibacter xylinus, c) Methylocella palustris, d) 'Ca. Brocadia sp.', e) 'Ca. Scalindua brodeae' and f) 'Ca. Kuenenia stuttgartiensis'. BHT isomers were identified based on relative retention times, in comparison to previously published stereochemical identification (Peiseler and Rohmer, 1992; Rosa-Putra et al., 2001).

anammox species ' $\mathrm{Ca}$. Scalindua brodeae' produced a late-eluting BHT isomer with a distinct retention time, which eluted after both BHT-34S and BHT-34R. We provisionally named this isomer "BHT$x$ " to reflect the distinct retention time, likely indicating a distinct stereochemistry. ' $\mathrm{Ca}$. S. profunda' BDE was not measured using the UHPLC-HRMS method, as the available BDE had been acetylated during a previous study (Rush et al., 2014). Furthermore, the freshwater anammox species ' $\mathrm{Ca}$. Kuenenia stuttgartiensis' did contain BHT-34S, but did not contain any of the other late-eluting BHT isomers - i.e. neither BHT-34R nor BHT- $x$ - (Fig. 2f), confirming the previous observation by Rush et al. (2014).

The $\mathrm{MS}^{2}$ spectra of BHT and late-eluting BHT isomers were too similar to allow discrimination between compounds with the different stereochemistries (Fig. 5).

\subsubsection{Purification and NMR spectroscopy analyses of BHT isomers}

The stereochemistries of the BHT isomers in M. palustris, ' $\mathrm{Ca}$. Brocadia sp.', ' $\mathrm{Ca}$. S. profunda' and 'Ca. S. brodeae' were not assessed by NMR spectroscopy. We attempted to isolate the lateeluting BHT isomers of ' $\mathrm{Ca}$. Scalindua brodeae' and ' $\mathrm{Ca}$. Brocadia sp.' to allow for direct NMR spectroscopy measurements. However, as anammox bacteria are slow-growing, insufficient biomass was obtained to allow isolation of the late-eluting BHT isomers separated from BHT-34S, and only an enriched BHT fraction was obtained from these two bacteria (Supplementary Material Section 3). Unfortunately, the amount of the $M$. palustris biomass was also insufficient to allow isolation of the late-eluting BHT isomer, and thus, acetylated M. palustris BDE was used only, in GC and HPLC analyses. It was decided to compare the chromatographic behaviour of the various isomers with confirmed standards of BHT-34S and BHT-34R. A specific protocol was used for isolating and preparing BHT-34R for use in this study (Supplementary Material Section 1), whereas a standard of acetylated BHT-34S previously isolated from Zymomonas mobilis was available (cf. Schaeffer et al., 2010). The stereochemistries of these standards were confirmed by NMR spectroscopy (Supplementary Material Table S2a-b and Fig. S2a-b). The ${ }^{1} \mathrm{H}$ and ${ }^{13} \mathrm{C}$ chemical shifts of the side chains of BHT-34R and BHT-34S standards were generally in agreement with those published for synthetic BHT-34R and BHT$34 S$ (Bisseret and Rohmer, 1989) and with BHT-34R isolated from K. xylinus (Peiseler and Rohmer, 1992; cf. Supplementary Material Section 2 for the ${ }^{1} \mathrm{H}$ and ${ }^{13} \mathrm{C}$ chemical shifts of the side chains from BHT-34R and BHT-34S).

\subsubsection{GC-FID analysis of acetylated BHT isomers by co-injections}

The identity of the BHT isomers present in the bacterial cultures and enrichments was evaluated using GC-FID analysis of acetylated BDEs (Frankia sp. strain Ea1-12, K. xylinus and M. palustris), or enriched BHT fractions (' $\mathrm{Ca}$. Scalindua brodeae' and ' $\mathrm{Ca}$. Brocadia sp.') (Fig. 3). All samples contained BHT-34S, as confirmed by GCFID co-injection with an authentic standard (Fig. 3). Co-injections of the authentic acetylated BHT-34R standard with acetylated extracts from Frankia sp. strain Ea1-12 (Fig. 3c), M. palustris (Fig. 3d), and the anammox bacterium 'Ca. Brocadia sp.' (Fig. 3e) confirmed the BHT-34R stereochemistry of the late-eluting BHT isomer of these cultures. The late-eluting BHT isomer (BHT- $x$ ) from 'Ca. S. brodeae' did not co-elute with BHT-34R (Fig. 3f). To verify that other species belonging to the genus $\mathrm{Ca}$. Scalindua also contain

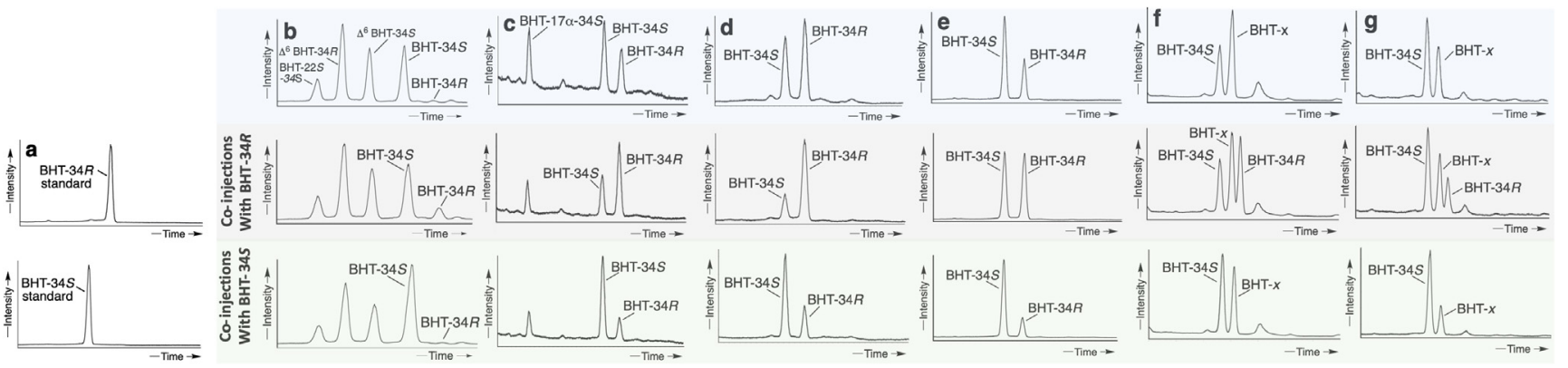

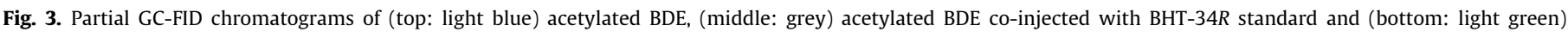

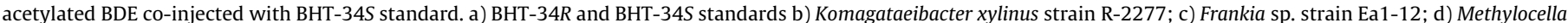

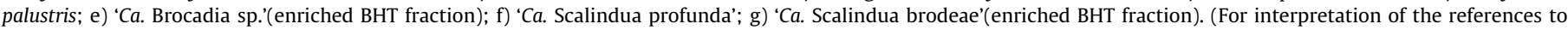
colour in this figure legend, the reader is referred to the web version of this article.) 


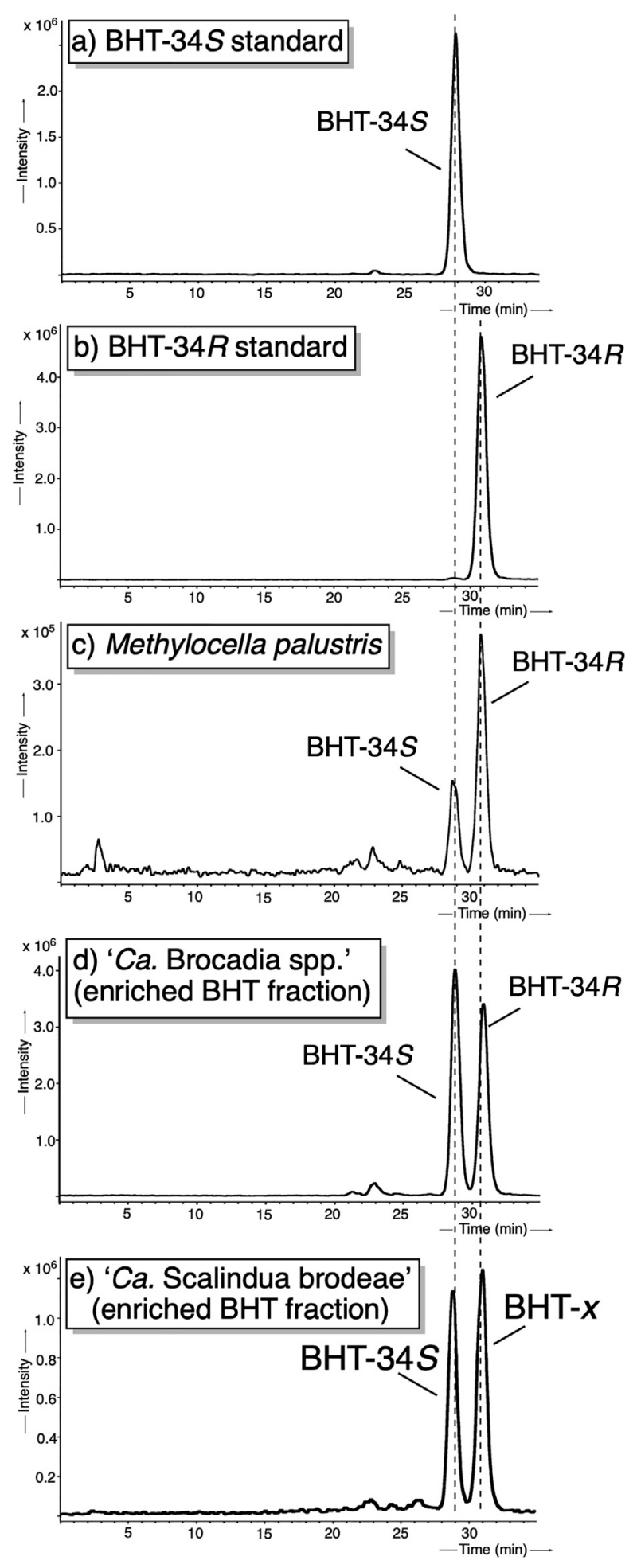

Fig. 4. HPLC-MS mass chromatograms ( $m / z$ 655) of acetylated a) BHT-34S standard; b) BHT-34R standard; c) BDE of Methylocella palustris; d) BDE 'Ca. Brocadia sp.'; e) BDE from ' $C a$. Scalindua brodeae'.

BHT- $x$ (Rush et al., 2014), acetylated 'Ca. S. profunda' TLE was also co-injected with authentic BHT standards (Fig. 3g). Both 'Ca. Scalindua' species were found to produce the BHT- $x$ isomer. Of the known bacterial producers of BHT isomers, BHT- $x$ is only synthesized by marine anammox bacteria, suggesting that it can be applied as a biomarker for paleo-marine anammox studies.
3.2. Implications for the analysis of BHT isomers in cultures and sediments

The isomer elution order of non-acetylated BHTs when measured by UHPLC-HRMS was different to that of the acetylated compounds examined by GC-FID or GC-MS. Non-acetylated BHT- $x$ eluted last on UHPLC, while eluting before BHT-34R on GC. BHT- $x$ displays the same mass spectrum, when analysed by GC-MS, as BHT-34S (cf. BHT (BHT-34S) and BHT' (i.e. BHT- $x$ ) in Lengger et al., 2019). GC-MS spectra of BHT-34S, BHT-34R, BHT- $x$, and 17a-BHT-34S can be found in Supplementary Material Section 4. The similarity in mass spectra, combined with distinct retention times by two chromatographic techniques, support the identification of BHT- $x$ as an isomer of BHT-34S. HPLC-APCI-MS analysis of acetylated BDE using a single column is a well-established method for examination of BHPs (e.g. Talbot et al., 2007a, b). However, while the single-column HPLC-APCI-MS method developed in the present study for analysis of acetylated BHTs does separate BHT$34 S$ from its late-eluting isomers, it does not provide distinct retention times for BHT-34R and BHT- $x$ (Fig. 4). As acetylated BHT analysis by HPLC-APCI-MS does not differentiate between late-eluting BHT isomers, BHT isomer studies should be performed by GC on acetylated BHTs or by UHPLC on non-acetylated BHTs. It should be noted that the triple column method for UHPLC analysis of acetylated BHPs (Kusch et al., 2018) was not tested in this study and future work should investigate whether this method would allow acetylated BHT-34R and BHT- $x$ to be distinguished. Previous HPLC studies of acetylated late-eluting BHT isomers assumed all the isomers were the same and any late-eluting BHT isomer was designated as "BHT II" (e.g. Sáenz et al., 2011; Matys et al., 2017, 2019; Kusch et al., 2018). As 'Ca. Scalindua sp.' synthesizes BHT- $x$ and currently is the only known marine bacterial source of any late-eluting BHT isomer, it is likely correct that these late-eluting BHT isomers isolated from anoxic marine systems had the same stereochemistry. However, the stereochemistry of a late-eluting BHT isomer in oxic and anoxic lacustrine systems was likewise identified and considered to be BHT II (e.g. Matys et al., 2019; Talbot et al., 2003). A late-eluting BHT isomer has also been found in oxic or seasonally anoxic marine settings (Kusch et al., 2018, 2019; Matys et al., 2019). In some of these cases, identification of the stereochemistry of the BHT isomer may reveal that it was not BHT- $x$, and thus not produced by 'Ca. Scalindua sp.', partially explaining its presence in oxic and/or non-marine environments. Furthermore, the ratio of late-eluting BHT isomer to total BHTs (BHT isomer ratio; Sáenz et al., 2011), derived from an acetylated culture analysed by HPLC with refractive index detection (ratio $=0.10$; Peiseler and Rohmer, 1992) is different from an aliquot of the same non-acetylated culture, analysed by UHPLC (ratio $=0.20$; this study) (Supplementary Material Section 5). Since the samples were extracted using similar, though not identical, methods (i.e., chloroform/methanol extraction $v s$. BDE), it seems more likely that instrumental differences caused the variation in observed BHT isomer ratio. We therefore advise against direct comparisons of BHT isomer fractional abundance performed using samples measured under different analytical conditions or instrumentation, without further investigation of which produces comparable BHT isomer ratios.

As multiple bacterial genera produce BHT-34R, additional measurements are required to elucidate the source of this biomarker in the environment. One potential method to differentiate these sources is by measuring the $\delta^{13} \mathrm{C}$ values of BHT-34R. Anammox bacteria have lipids that are ${ }^{13} \mathrm{C}$-depleted by up to $47 \%$ o versus the $\mathrm{CO}_{2}$ substrate (Schouten et al., 2004), resulting from their use of the acetyl coenzyme A pathway for carbon fixation (Strous et al., 2006). The $\delta^{13} \mathrm{C}$ values of late-eluting BHT isomer from sediments taken from a Mediterranean sapropel and the Arabian Sea 


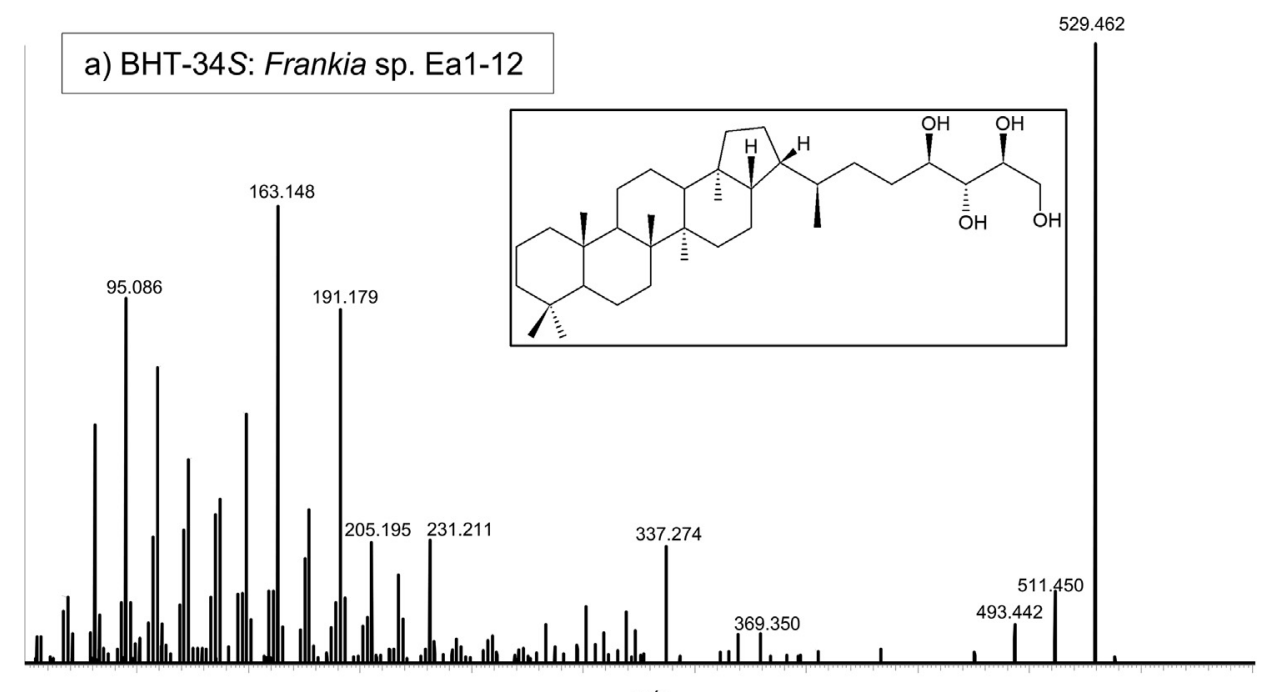

$m / z$

b) BHT-34R: Frankia sp. Ea1-12
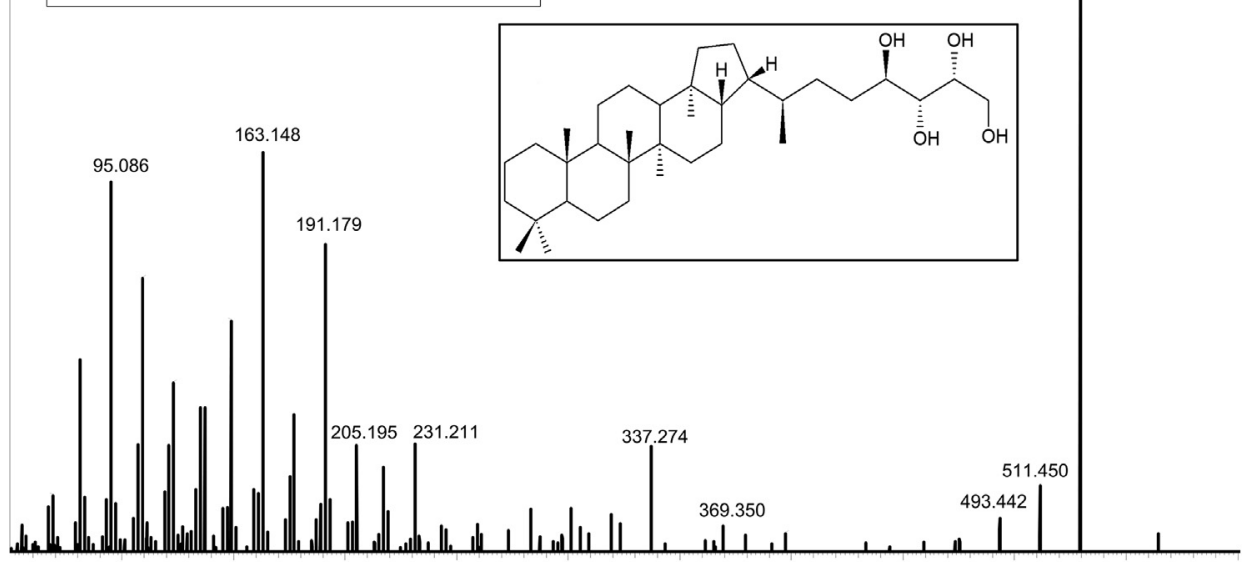

529.462

$m / z$

c) BHT-x: 'Ca. Scalindua brodeae'

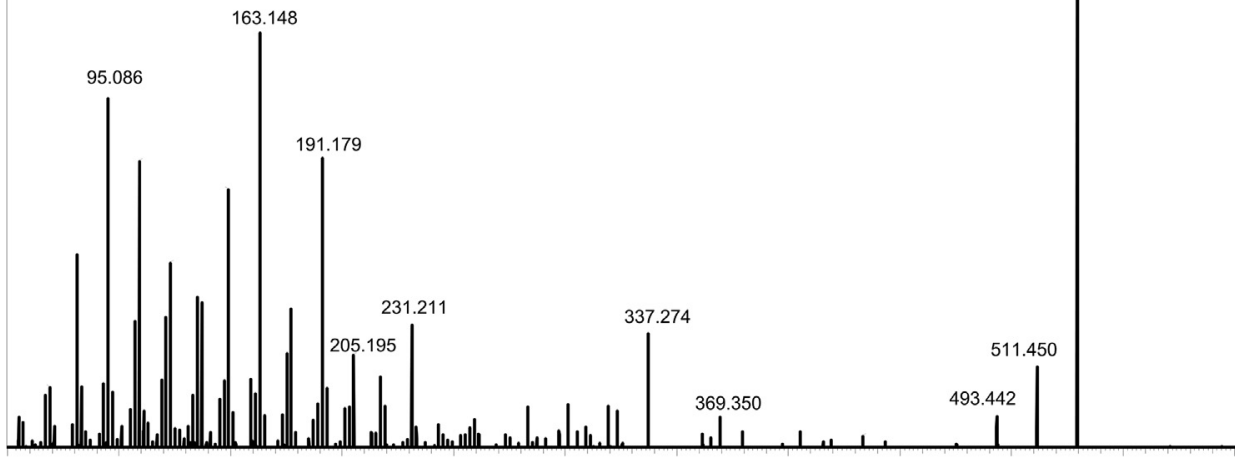

$m / z$

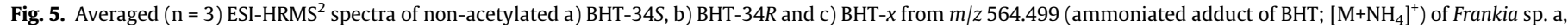
b) and 'Ca. Scalindua brodeae' c). Likely fragmentation patterns have been shown by Rush et al. (2019).

oxygen minimum zone were ${ }^{13} \mathrm{C}$-depleted, and had lower $\delta^{13} \mathrm{C}$ values than those of BHT-34S in the same samples, suggesting a marine anammox source of late-eluting BHT isomer in both cases (Hemingway et al., 2018; Lengger et al., 2019). The additional application of compound specific carbon isotopic analysis to nonmarine samples could differentiate between BHT-34R produced by anammox and by some other bacterial sources; if possible, $\delta^{13} \mathrm{C}$ analyses, as well as stereoisomer identification, should be 
conducted (Hemingway et al., 2018; Lengger et al., 2019). BHT-34R produced by the methanotrophic bacterium $M$. palustris may also have a low $\delta^{13} \mathrm{C}$ value, but Type II methanotrophs do not have consistently low lipid $\delta^{13} \mathrm{C}$ values (Kool et al., 2014). Future work is required to differentiate the carbon isotopic composition of BHT$34 R$ produced by 'Ca. Brocadia sp.' and M. palustris, as well as the other bacterial producers of this isomer.

'Ca. Scalindua brodeae' and 'Ca. Brocadia sp.' are both anaerobic anammox bacteria and evolved from a common ancestor (Strous et al., 2006). However, 'Ca. Brocadia sp.' synthesizes the same BHT isomer (BHT-34R) as non-marine, aerobic bacteria. Another freshwater species of anammox bacteria, 'Ca. Kuenenia stuttgartiensis' does not produce significant quantities of any BHT isomer other than the BHT-34S. Currently, we cannot identify either genetic or environmental factors common to BHT isomer production in all bacteria. Future studies should focus on the gene(s) responsible for hopanoid biosynthesis. However, as species of marine genus ' $\mathrm{Ca}$. Scalindua' are so far the only identified producers of BHT- $x$, it appears that BHT- $x$ can be confidently applied as a biomarker for marine anammox in the sedimentary record.

\section{Conclusions}

Five non-marine bacteria (Frankia spp., A. pasteurianus, K. xylinus, M. palustris and 'Ca. Brocadia sp.') were shown to synthesize BHT-34R. While this bacterial lipid is not specific to a class of organism, its use along with other evidence (e.g. $\delta^{13} \mathrm{C}$ values of BHT-34R) may be suggestive of its producers in the environment, including the non-marine anammox bacteria 'Ca. Brocadia sp.'. ' $\mathrm{Ca}$. Scalindua profunda' and ' $\mathrm{Ca}$. Scalindua brodeae' are the only known producers of BHT- $x$ (a BHT with an unidentified side chain stereochemistry), making this isomer a valuable biomarker for marine anammox. BHT-34S eluted before BHT-34R and BHT- $x$ by all methods tested. However, BHT-34R eluted before BHT- $x$ by UHPLC analysis of non-acetylated BHPs, after BHT- $x$ by GC analysis of acetylated BHPs and co-eluted with BHT- $x$ by HPLC analysis of acetylated BHPs. The choice of chromatography and derivatization methods should be carefully considered in future BHT isomer studies, so marine anammox can be distinguished from non-marine inputs.

\section{Declaration of Competing Interest}

The authors declare that they have no known competing financial interests or personal relationships that could have appeared to influence the work reported in this paper.

\section{Acknowledgments}

Funding was obtained through Natural Environment Research Council (NERC), United Kingdom project ANAMMARKS (NE/ N011112/1) awarded to DR, SIAM, Netherlands 024002002 awarded to MJ and an EAOG, Netherlands Research Award to RSN. SKL was supported by Rubicon fellowship nr. 825.14.014 from the Netherlands Organization for Scientific Research (NWO), Netherlands. Further support came from the European Research Council (ERC), European Union under the European Union's Horizon 2020 research and innovation program (grant agreement no. 694569 - MICROLIPIDS) to JSSD. We also acknowledge support through The Leverhulme Trust, United Kingdom (Grant RPG2016$050)$ to JCM. The authors declare no competing financial or nonfinancial interests. We thank the Newcastle and NIOZ technical staff (David Earley; Paul Donohoe; Denise van der SlikkeDorhout). We thank Prof. M. Rohmer for providing Komagataeibacter xylinus and Mrs Pascale Fournier (Université Lyon) for growth of the Frankia sp. isolate. Dr. Sémeril (Université de Strasbourg) is greatly acknowledged for his help in the experiments of hydrogenation under pressure, of unsaturated BHTs. We thank Katinka van de Pas-Schoonen for running the Brocadia bioreactor. We thank reviewers Dr Kusch and Dr Hemingway for their substantive comments which improved the manuscript, as well as the editors of Organic Geochemistry.

\section{Appendix A. Supplementary material}

Supplementary data to this article can be found online at https://doi.org/10.1016/j.orggeochem.2020.103994.

\section{References}

Alloisio, N., Queiroux, C., Fournier, P., Pujic, P., Normand, P., Vallenet, D., Médigue, C., Yamaura, M., Kakoi, K., Kucho, K., 2010. The Frankia alni symbiotic transcriptome. Molecular Plant-Microbe Interactions 23, 593-607. https://doi org/10.1094/MPMI-23-5-0593.

Belin, B.J., Busset, N., Giraud, E., Molinaro, A., Silipo, A., Newman, D.K., 2018. Hopanoid lipids: from membranes to plant-bacteria interactions. Nature Reviews Microbiology 16, 304-315. https://doi.org/10.1038/nrmicro.2017.173.

Berndmeyer, C., Thiel, V., Schmale, O., Blumenberg, M., 2013. Biomarkers for aerobic methanotrophy in the water column of the stratified Gotland Deep (Baltic Sea). Organic Geochemistry 55, 103-111. https://doi.org/10.1016/J. ORGGEOCHEM.2012.11.010.

Berndmeyer, C., Thiel, V., Schmale, O., Wasmund, N., Blumenberg, M., 2014. Biomarkers in the stratified water column of the Landsort Deep (Baltic Sea) Biogeosciences 11, 7009-7023. https://doi.org/10.5194/bg-11-7009-2014.

Besseling, M.A., Hopmans, E.C., Boschman, R.C., Sinninghe Damsté, J.S., Villanueva, L., 2018. Benthic archaea as potential sources of tetraether membrane lipids in sediments across an oxygen minimum zone. Biogeosciences 15, 4047-4064. https://doi.org/10.5194/bg-15-4047-2018.

Bisseret, P., Rohmer, M., 1989. Bacterial sterol surrogates. Determination of the absolute configuration of bacteriohopanetetrol side chain by hemisynthesis of its diastereoisomers. Journal of Organic Chemistry 54, 2958-2964. https://doi. org/10.1021/jo00273a034.

Blumenberg, M., Mollenhauer, G., Zabel, M., Reimer, A., Thiel, V., 2010. Decoupling of bio- and geohopanoids in sediments of the Benguela Upwelling System (BUS). Organic Geochemistry 41, 1119-1129. https://doi.org/10.1016/J. ORGGEOCHEM.2010.06.005.

Cooke, M.P., Talbot, H.M., Wagner, T., 2008. Tracking soil organic carbon transport to continental margin sediments using soil-specific hopanoid biomarkers: a case study from the Congo fan (ODP site 1075). Organic Geochemistry 39, 965-971. https://doi.org/10.1016/j.orggeochem.2008.03.009.

Crombie, A.T., Murrell, J.C., 2014. Trace-gas metabolic versatility of the facultative methanotroph Methylocella silvestris. Nature 510, 148-151. https://doi.org/ $10.1038 /$ nature13192.

Farhan Ul Haque, M., Crombie, A.T., Murrell, J.C., 2019. Novel facultative Methylocella strains are active methane consumers at terrestrial natural gas seeps. Microbiome 7. https://doi.org/10.1186/s40168-019-0741-3.

Fernandez, M.P., Meugnier, H., Grimont, P.A.D., Bardin, R., 1989. Deoxyribonucleic acid relatedness among members of the genus Frankia. International Journal of Systematic Bacteriology 39, 424-429. https://doi.org/10.1099/00207713-39-4424.

Hemingway, J.D., Kusch, S., Shah Walter, S.R., Polik, C.A., Elling, F.J., Pearson, A., 2018. A novel method to measure the ${ }^{13} \mathrm{C}$ composition of intact bacteriohopanepolyols. Organic Geochemistry 123, 144-147. https://doi.org/ 10.1016/J.ORGGEOCHEM.2018.07.002.

Jaeschke, A., Lewan, M.D., Hopmans, E.C., Schouten, S., Sinninghe Damsté, J.S., 2008 Thermal stability of ladderane lipids as determined by hydrous pyrolysis. Organic Geochemistry 39, 1735-1741. https://doi.org/10.1016/j. orggeochem.2008.08.006.

Kartal, B., Rattray, J., van Niftrik, L.A., van de Vossenberg, J., Schmid, M.C., Webb, R.I., Schouten, S., Fuerst, J.A., Sinninghe Damsté, J.S., Jetten, M.S.M., Strous, M., 2007. Candidatus "Anammoxoglobus propionicus" a new propionate oxidizing species of anaerobic ammonium oxidizing bacteria. Systematic and Applied Microbiology 30, 39-49. https://doi.org/10.1016/J.SYAPM.2006.03.004.

Kartal, B., Keltjens, J.T., Jetten, M.S.M. 2011. Metabolism and genomics of anammox bacteria. In: Nitrification (Ward B. B., Arp D. J., Klotz M. G, Eds), Chapter 8, 181200. American Society of Microbiology. 10.1128/9781555817145.ch8.

Kharbush, J.J., Ugalde, J.A., Hogle, S.L., Allen, E.E., Aluwihare, L.I., 2013. Composite bacterial hopanoids and their microbial producers across oxygen gradients in the water column of the California Current. Applied and Environmental Microbiology 79, 7491-7501. https://doi.org/10.1128/AEM.02367-13.

Kool, D.M., Talbot, H.M., Rush, D., Ettwig, K., Sinninghe Damsté, J.S., 2014. Rare bacteriohopanepolyols as markers for an autotrophic, intra-aerobic methanotroph. Geochimica et Cosmochimica Acta 136, 114-125. https://doi. org/10.1016/j.gca.2014.04.002.

Kusch, S., Shah Walter, S.R., Hemingway, J.D., Pearson, A., 2018. Improved chromatography reveals multiple new bacteriohopanepolyol isomers in 
marine sediments. Organic Geochemistry 124, 12-21. https://doi.org/10.1016/J. ORGGEOCHEM.2018.07.010.

Kusch, S., Sepúlveda, J., Wakeham, S.G., 2019. Origin of sedimentary BHPs along a Mississippi River-Gulf of Mexico export transect: Insights from spatial and density distributions. Frontiers in Marine Science. https://doi.org/10.3389/ fmars.2019.00729.

Kuypers, M.M.M., Sliekers, A.O., Lavik, G., Schmid, M., Jørgensen, B.B., Kuenen, J.G., Sinninghe Damsté, J.S., Strous, M., Jetten, M.S.M., 2003. Anaerobic ammonium oxidation by anammox bacteria in the Black Sea. Nature 422, 608-611. https:// doi.org/10.1038/nature01472.

Lengger, S., Rush, D., Mayser, J.P., Blewett, J., Schwartz-Narbonne, R., Talbot, H., Middelburg, J., Jetten, M.S.M., Schouten, S., Sinninghe Damsté, J.S., Pancost, R.D., 2019. Dark carbon fixation in the Arabian Sea oxygen minimum zone contributes to sedimentary organic carbon (SOM). Global Biogeochemical Cycles 33 (2019), 1715-1732. https://doi.org/10.1029/2019GB006282.

Matys, E.D., Sepúlveda, J., Pantoja, S., Lange, C.B., Caniupán, M., Lamy, F., Summons, R.E., 2017. Bacteriohopanepolyols along redox gradients in the Humboldt Current System off northern Chile. Geobiology 15, 844-857. https://doi.org/ $10.1111 /$ GBI.12250.

Matys, E.D., Mackey, T., Grettenberger, C., Mueller, E., Jungblut, A., Sumner, D.Y., Hawes, I., Summons, R.E., 2019. Environmental controls on bacteriohopanepolyol profiles of benthic microbial mats from Lake Fryxell, Antarctica. Geobiology 17, 551-563. https://doi.org/10.1111/gbi.12353.

Peiseler, B., Rohmer, M., 1992. Prokaryotic triterpenoids of the hopane series. Bacteriohopanetetrols of new side-chain configuration from Acetobacter species. Journal of Chemical Research, 298-299.

Quan, Z.-X., Rhee, S.-K., Zuo, J.-E., Yang, Y., Bae, J.-W., Park, J.R., Lee, S.-T., Park, Y.-H., 2008. Diversity of ammonium-oxidizing bacteria in a granular sludge anaerobic ammonium-oxidizing (anammox) reactor. Environmental Microbiology 10, 3130-3139. https://doi.org/10.1111/j.1462-2920.2008.01642.x.

Rohmer, M., Bouvier-Nave, P., Ourisson, G., 1984. Distribution of hopanoid triterpenes in Prokaryotes. Microbiology 130, 1137-1150. https://doi.org/ 10.1099/00221287-130-5-1137.

Rosa-Putra, S., Nalin, R., Domenach, A.-M., Rohmer, M., 2001. Novel hopanoids from Frankia spp. and related soil bacteria. European Journal of Biochemistry 268 4300-4306. https://doi.org/10.1046/j.1432-1327.2001.02348.x.

Rush, D., Sinninghe Damsté, J.S., 2017. Lipids as paleomarkers to constrain the marine nitrogen cycle. Environmental Microbiology 19, 2119-2132. https://doi. org/10.1111/1462-2920.13682 doi: 10.1111/1462-2920.13682.

Rush, D., Hopmans, E.C., Wakeham, S.G., Schouten, S., Sinninghe Damsté, J.S., 2012. Occurrence and distribution of ladderane oxidation products in different oceanic regimes. Biogeosciences 9, 2407-2418. https://doi.org/10.5194/bg-92407-2012.

Rush, D., Sinninghe Damsté, J.S., Poulton, S.W., Thamdrup, B., Garside, A.L., Acuña González, J., Schouten, S., Jetten, M.S.M., Talbot, H.M., 2014. Anaerobic ammonium-oxidising bacteria: A biological source of the bacteriohopanetetrol stereoisomer in marine sediments. Geochimica et Cosmochimica Acta 140, 50-64. https://doi.org/10.1016/j.gca.2014.05.014.

Rush, D., Talbot, H.M., van der Meer, M.T.J., Hopmans, E.C., Douglas, B., Sinninghe Damsté, J.S., 2019. Biomarker evidence for the occurrence of anaerobic ammonium oxidation in the eastern Mediterranean Sea during Quaternary and Pliocene sapropel formation. Biogeosciences 16, 2467-2479. https://doi. org/10.5194/bg-16-2467-2019.

Russ, L., Speth, D.R., Jetten, M.S.M., Op den Camp, H.J.M., Kartal, B., 2014 Interactions between anaerobic ammonium and sulfur-oxidizing bacteria in laboratory scale model system. Environmental Microbiology 16, 3487-3498. https://doi.org/10.1016/j.orggeochem.2010.04.013.

Sáenz, J.P., Wakeham, S.G., Eglinton, T.I., Summons, R.E., 2011. New constraints on the provenance of hopanoids in the marine geologic record: Bacteriohopanepolyols in marine suboxic and anoxic environments. Organic Geochemistry 42, 1351-1362. https://doi.org/10.1016/j. orggeochem.2011.08.016

Schaeffer, P., Schmitt, G., Adam, P., Rohmer, M., 2010. Abiotic formation of 32,35anhydrobacteriohopanetetrol: A geomimetic approach. Organic Geochemistry 41, 1005-1008. https://doi.org/10.1016/j.orggeochem.2010.04.013.

Schmid, M., Twachtmann, U., Klein, M., Strous, M., Juretschko, S., Jetten, M.S.M., Metzger, J.W., Schleifer, K.-H., Wagner, M., 2000. Molecular evidence for genus level diversity of bacteria capable of catalyzing anaerobic ammonium oxidation. Systematic and Applied Microbiology 23, 93-106. https://doi.org/10.1016 S0723-2020(00)80050-8.

Schmid, M.C., Risgaard-Petersen, N., van de Vossenberg, J., Kuypers, M.M.M., Lavik, G., Petersen, J., Hulth, S., Thamdrup, B., Canfield, D., Dalsgaard, T., Rysgaard, S. Sejr, M.K., Strous, M., Op den Camp, H.J.M., Jetten, M.S.M., 2007. Anaerobic ammonium-oxidizing bacteria in marine environments: widespread occurrence but low diversity. Environmental Microbiology 9, 1476-1484. https://doi.org 10.1111/j.1462-2920.2007.01266.x.

Schouten, S., Strous, M., Kuypers, M.M.M., Rijpstra, W.I.C., Baas, M., Schubert, C.J., Jetten, M.S.M., Sinninghe Damsté, J.S., 2004. Stable carbon isotopic fractionations associated with inorganic carbon fixation by anaerobic ammonium-oxidizing bacteria. Applied and Environmental Microbiology 70, 3785-3788. https://doi.org/10.1128/AEM.70.6.3785-3788.2004.

Sinninghe Damsté, J.S., Strous, M., Rijpstra, W.I.C., Hopmans, E.C., Geenevasen, J.A.J., van Duin, A.C.T., van Niftrik, L.A., Jetten, M.S.M., 2002. Linearly concatenated cyclobutane lipids form a dense bacterial membrane. Nature 419, 708-712. https://doi.org/10.1038/nature01128.
Sinninghe Damsté, J.S., Rijpstra, W.I.C., Schouten, S., Fuerst, J.A., Jetten, M.S.M., Strous, M., 2004. The occurrence of hopanoids in planctomycetes: implications for the sedimentary biomarker record. Organic Geochemistry 35, 561-566. https://doi.org/10.1016/j.orggeochem.2004.01.013.

Speth, D.R., Russ, L., Kartal, B., Op den Camp, H.J.M., Dutilh, B.E., Jetten, M.S.M., 2015. Draft genome sequence of anammox bacterium "Candidatus Scalindua brodeae" obtained using differential coverage binning of sequencing data from two reactor enrichments. Genome Announcements 3, e01415-e1514. https://doi. org/10.1128/genomeA.01415-14.

Strous, M., Fuerst, J.A., Kramer, E.H.M., Logemann, S., Muyzer, G., van de PasSchoonen, K.T., Webb, R., Kuenen, J.G., Jetten, M.S.M., 1999. Missing lithotroph identified as new planctomycete. Nature 400, 446-449. https://doi.org/ $10.1038 / 22749$.

Strous, M., Pelletier, E., Mangenot, S., Rattei, T., Lehner, A., Taylor, M.W., Horn, M., Daims, H., Bartol-Mavel, D., Wincker, P., Barbe, V., Fonknechten, N., Vallenet, D., Segurens, B. Schenowitz-Truong C., Médigue, C., Collingro, A., Snel, B., Dutilh, B. E., Op den Camp, H.J.M., van der Drift, C., Cirpus, I., van de Pas-Schoonen, K.T., Harhangi, H.R., van Niftrik, L., Schmid, M., Keltjens, J., van de Vossenberg, J., Kartal, B., Meier, H., Frishman, D., Huynen, M.A., Mewes, H.-W., Weissenbach, J., Jetten, M.S.M., Wagner, M., Le Paslier, D., 2006. Deciphering the evolution and metabolism of an anammox bacterium from a community genome. Nature 440 , 790-794. https://doi.org/10.1038/nature04647.

Talbot, H.M., Farrimond, P., 2007. Bacterial populations recorded in diverse sedimentary biohopanoid distributions. Organic Geochemistry 38, 1212-1225. https://doi.org/10.1016/j.orggeochem.2007.04.006.

Talbot, H.M., Watson, D.F., Pearson, E.J., Farrimond, P., 2003. Diverse biohopanoid compositions of non-marine sediments. Organic Geochemistry 34, 1353-1371. https://doi.org/10.1016/S0146-6380(03)00159-1.

Talbot, H.M., Rohmer, M., Farrimond, P., 2007a. Rapid structural elucidation of composite bacterial hopanoids by atmospheric pressure chemical ionisation liquid chromatography/ion trap mass spectrometry. Rapid Communications in Mass Spectrometry 21, 880-892. https://doi.org/10.1002/rcm.2911.

Talbot, H.M., Rohmer, M., Farrimond, P., 2007b. Structural characterisation of unsaturated bacterial hopanoids by atmospheric pressure chemical ionisation liquid chromatography/ion trap mass spectrometry. Rapid Communications in Mass Spectrometry 21, 1613-1622. https://doi.org/10.1002/rcm.2997.

Talbot, H.M., Coolen, M.J.L., Sinninghe Damsté, J.S., 2008. An unusual 17 $\alpha, 21 \beta(H)-$ bacteriohopanetetrol in Holocene sediments from Ace Lake (Antarctica). Organic Geochemistry 39, 1029-1032. https://doi.org/10.1016/j. orggeochem.2008.01.008.

Talbot, H.M., Bischoff, J., Inglis, G.N., Collinson, M.E., Pancost, R.D., 2016. Polyfunctionalised bio- and geohopanoids in the Eocene Cobham Lignite. Organic Geochemistry 96, 77-92. https://doi.org/10.1016/J. ORGGEOCHEM.2016.03.006.

Van de Graaf, A.A., Mulder, A.R., de Bruijn, P.E., Jetten, M.S., Robertson, L.A., Kuenen, J.G., 1995. Anaerobic oxidation of ammonium is a biologically mediated process. Applied and Environmental Microbiology 61, 1246-1251.

van de Vossenberg, J., Rattray, J.E., Geerts, W., Kartal, B., van Niftrik, L., van Donselaar, E.G., Sinninghe Damsté, J.S., Strous, M., Jetten, M.S.M., 2008. Enrichment and characterization of marine anammox bacteria associated with global nitrogen gas production. Environmental Microbiology 10, 31203129. https://doi.org/10.1111/j.1462-2920.2008.01643.x.

van de Vossenberg, J., Woebken, D., Maalcke, W.J., Wessels, H.J.C.T., Dutilh, B.E., Kartal, B., Janssen-Megens, E.M., Roeselers, G., Yan, J., Speth, D., Gloerich, J., Geerts, W., van der Biezen, E., Pluk, W., Francoijs, K.-J., Russ, L., Lam, P., Malfatti, S.A., Tringe, S.G., Haaijer, S.C.M., Op den Camp, H.J.M., Stunnenberg, H.G., Amann, R., Kuypers, M.M.M., Jetten, M.S.M., 2013. The metagenome of the marine anammox bacterium 'Candidatus Scalindua profunda' illustrates the versatility of this globally important nitrogen cycle bacterium. Environmental Microbiology 15, 1275-1289. https://doi.org/10.1111/j.1462-2920.2012.02774.

van Dongen, B.E., Talbot, H.M., Schouten, S., Pearson, P.N., Pancost, R.D., 2006. Well preserved Palaeogene and Cretaceous biomarkers from the Kilwa area, Tanzania. Organic Geochemistry 37, 539-557. https://doi.org/10.1016/j. orggeochem.2006.01.003.

van Winden, J.F., Talbot, H.M., Kip, N., Reichart, G.-J., Pol, A., McNamara, N.P., Jetten, M.S.M., Op den Camp, H.J.M., Sinninghe Damsté, J.S., 2012. Bacteriohopanepolyol signatures as markers for methanotrophic bacteria in peat moss. Geochimica et Cosmochimica Acta 77, 52-61. https://doi.org/ 10.1016/j.gca.2011.10.026

Villanueva, L., Speth, D.R., van Alen, T., Hoischen, A., Jetten, M.S.M., 2014. Shotgun metagenomic data reveals significant abundance but low diversity of "Candidatus Scalindua" marine anammox bacteria in the Arabian Sea oxygen minimum zone. Frontiers in Microbiology 5, 31. https://doi.org/10.3389/ fmicb.2014.00031.

Wakeham, S.G., Turich, C., Schubotz, F., Podlaska, A., Li, X.N., Varela, R., Astor, Y., Sáenz, J.P., Rush, D., Sinninghe Damsté, J.S., Summons, R.E., Scranton, M.I., Taylor, G.T., Hinrichs, K.-U., 2012. Biomarkers, chemistry and microbiology show chemoautotrophy in a multilayer chemocline in the Cariaco Basin. DeepSea Research Part I: Oceanographic Research Papers 63, 133-156. https://doi. org/10.1016/j.dsr.2012.01.005.

Wang, J., Gu, J.-D., 2013. Dominance of Candidatus Scalindua species in anammox community revealed in soils with different duration of rice paddy cultivation in Northeast China. Applied Microbiology and Biotechnology 97, 1785-1798. https://doi.org/10.1007/s00253-012-4036-x. 
Ward, B.B., 2013. How nitrogen is lost. Science 341, 352-353. https://doi.org/ 10.1126/science.1240314.

Woebken, D., Fuchs, B.M., Kuypers, M.M.M., Amann, R., 2007. Potential interactions of particle-associated anammox bacteria with bacterial and archaeal partners in the Namibian upwelling system. Applied and Environmental Microbiology 73, 4648-4657. https://doi.org/10.1128/AEM.02774-06.
Wörmer, L., Lipp, J.S., Schröder, J.M., Hinrichs, K.U., 2013. Application of two new LC-ESI-MS methods for improved detection of intact polar lipids (IPLs) in environmental samples. Organic Geochemistry 59, 10-21. https://doi.org/ 10.1016/j.orggeochem.2013.03.004. 